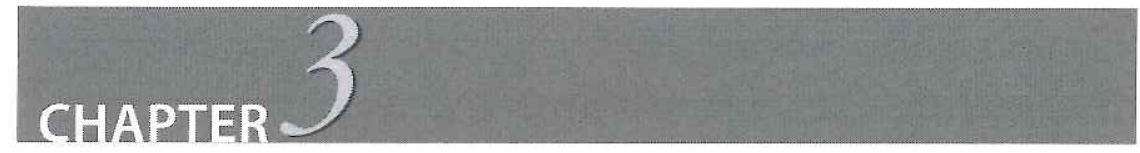

\title{
Crown Rot Disease of Bananas
}

\section{Ludivine Lassois ${ }^{1}$ and Luc de Lapeyre de Bellaire ${ }^{2}$}

${ }^{1}$ Forest, Nature and Lanscape Department, Liège University, Gembloux Agro-Bio Tech, Gembloux, Belgium; ${ }^{2} \mathrm{CIRAD}$, Research Unit Banana, Plantain and Pineapple Cropping Systems, Montpellier, France

\section{Contents}

Overall Importance of the Disease 104

$\begin{array}{ll}\text { Taxonomy and Morphology } & 107\end{array}$

Biology of Crown rot Infection Process 109

Field Contamination 109

Conidial Dispersion 109

Fruit Contamination in the Field $\quad 110$

Fruit Contamination in the Packing Station $\quad 110$

Preharvest Factors Favoring Crown Rot Disease 111

Influence of Environmental Factors on the Potential of Quality 112

Influence of Harvest Stage on Fruit Susceptibility 113

Influence of Source/Sink Ratio on Fruit Susceptibility 113

Effect of Some Biotic Factors on Fruit Susceptibility 114

Influence of Sanitation Practices on Fruit Contamination 114

Postharvest Factors Favoring Crown Rot Disease 114

Organization of the Banana Commodity Channel 115

Control Methods and Alternatives to Chemical Control 115

Conventional Chemical Control 115

Non-Conventional Control 117

Field Control Methods $\quad 117$

Postharvest Control Methods $\quad 119$

Controlled and Modified Atmospheres $\quad 121$

Hot Water Treatments (HWT) 121

UV and Gamma Radiation Treatment 122

Biological Control $\quad 122$

Natural Compounds $\quad 123$

Concluding Remarks 124

References 124 


\section{OVERALL IMPORTANCE OF THE DISEASE}

Crown rot disease is considered to be the main export banana postharvest disease (Reyes et al., 1998; Krauss and Johanson, 2000) and it affects export bananas in all banana-producing countries. Crown rot affects tissues of the so-called 'crown', which unites the peduncles (Fig. 3.1A). Since crowns are mainly infected at harvest time, future infection is unpredictable. The symptoms develop rapidly during shipping and ripening when the physiology of the fruit undergoes modifications that facilitate fungal development (Jones, 2000). The rot begins with mycelial development on the surface of the crown (Fig. 3.1B), followed by the peduncles and fruit (Fig. 3.1C-F). The bananas may detach from the peduncle in cases of severe infection. Crown rot results from the development in the crown of several common fungi, which constitute a fungal complex, and leads to softening and blackening of tissues at the site of the wound left when the cluster was cut from the bunch.

Crown rot affects the fruit quality because of the development of necrosis on the fruit, and it can also trigger early ripening of bananas during shipping (Peacock, 1973). Ripening may be caused by ethylene released by stressed and necrotic tissues (Simmonds, 1963; MacCracken and Swinburne, 1980; Dominguez and Vendrell, 1993) but also by ethylene produced by mycelia of fungi such as Colletotrichum musae (Peacock and Muirhead, 1974; Daundasekera et al., 2003). The result is a green life reduction and an accelerated maturation of the fruits. Overall, crown rot incidence involves a depreciation of the product inducing significant economic losses. Onset of the disease cannot be predicted and it spreads in an irregular pattern on all clusters in a shipping box. The same box may contain both healthy and infected clusters. The incidence of crown rot periodically increases during the rainy season, and losses of over $10 \%$ have been recorded in the UK in bananas coming from the Windward Islands that were harvested during this period (Krauss and Johanson, 2000). Losses of up to $86 \%$ have also been reported in non-chemically treated bananas from the Philippines (Alvindia et al., 2000).

Crown rot disease became a major problem in the banana industry during varietal reconversion initiatives in the 1960s. Up until 1960, only Gros-Michel subgroup cultivars were cropped for export, and for economic and practical reasons bananas were shipped in complete bunches consisting of double layers of fruits, called hands, which are arranged helicoidally around a central axis called the stalk. These cultivars were, however, susceptible to Panama disease (Fusarium oxysporum f.sp. cubense) and 


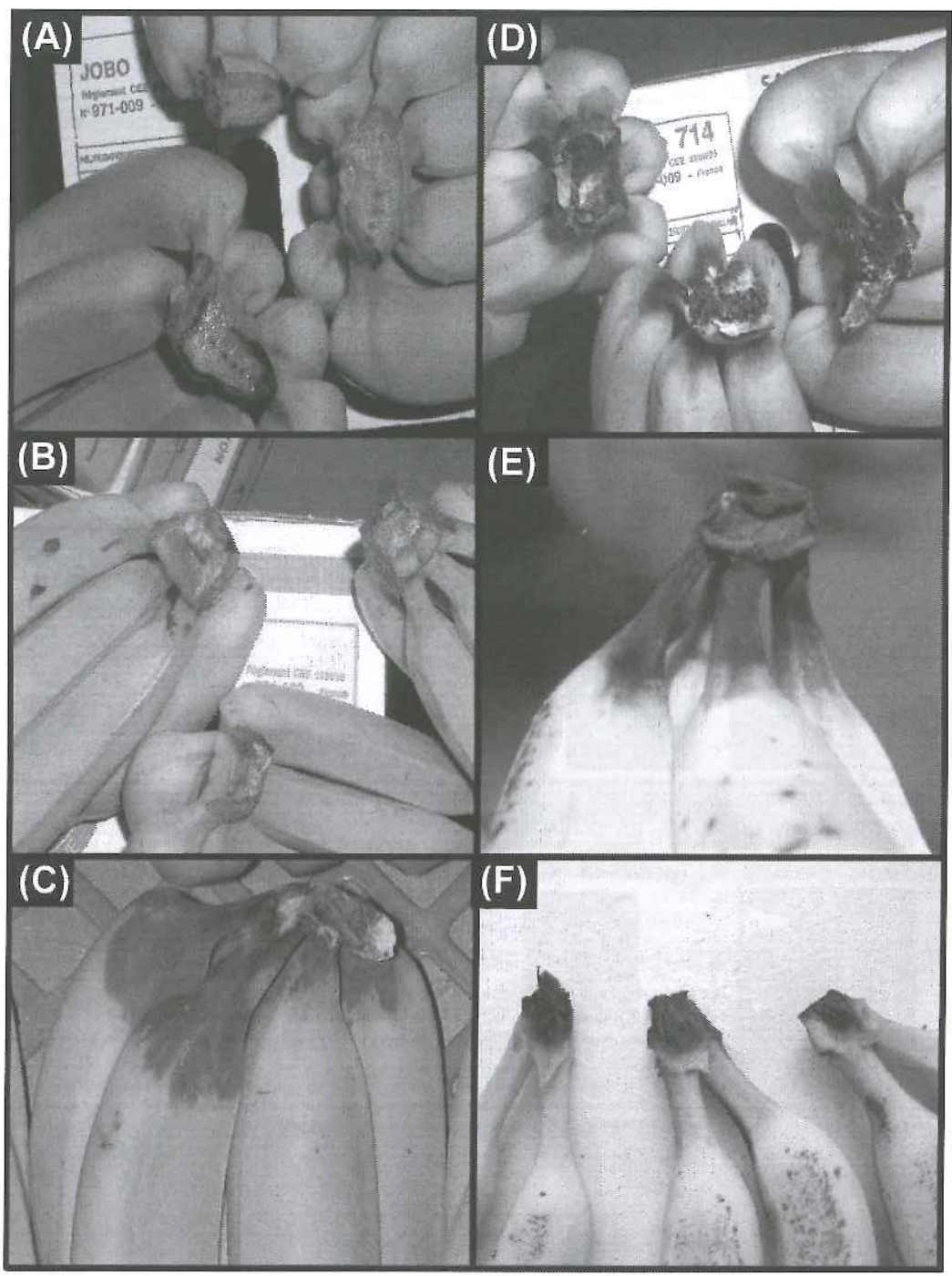

Figure 3.1 Crown rot symptoms. (A) Healthy crowns after maritime shipping before being placed in ripening rooms. (B) Crowns diseased with a superficial mycelium after maritime shipping. (C) Rot noted on bananas after maritime shipping. (D) Rot on the peduncles inducing banana ripening upon their arrival after maritime shipping. (E) External crown rot symptoms after fruit ripening. (F) Internal crown rot symptoms after fruit ripening (Lassois et al., 2010b).

thus were replaced by Cavendish subgroup cultivars because of their resistance to Panama disease (Stover, 1972). However, Cavendish bananas are more fragile during shipping and this triggered a revolution in the banana industry as bunch shipping was discontinued. Bananas were instead cut 


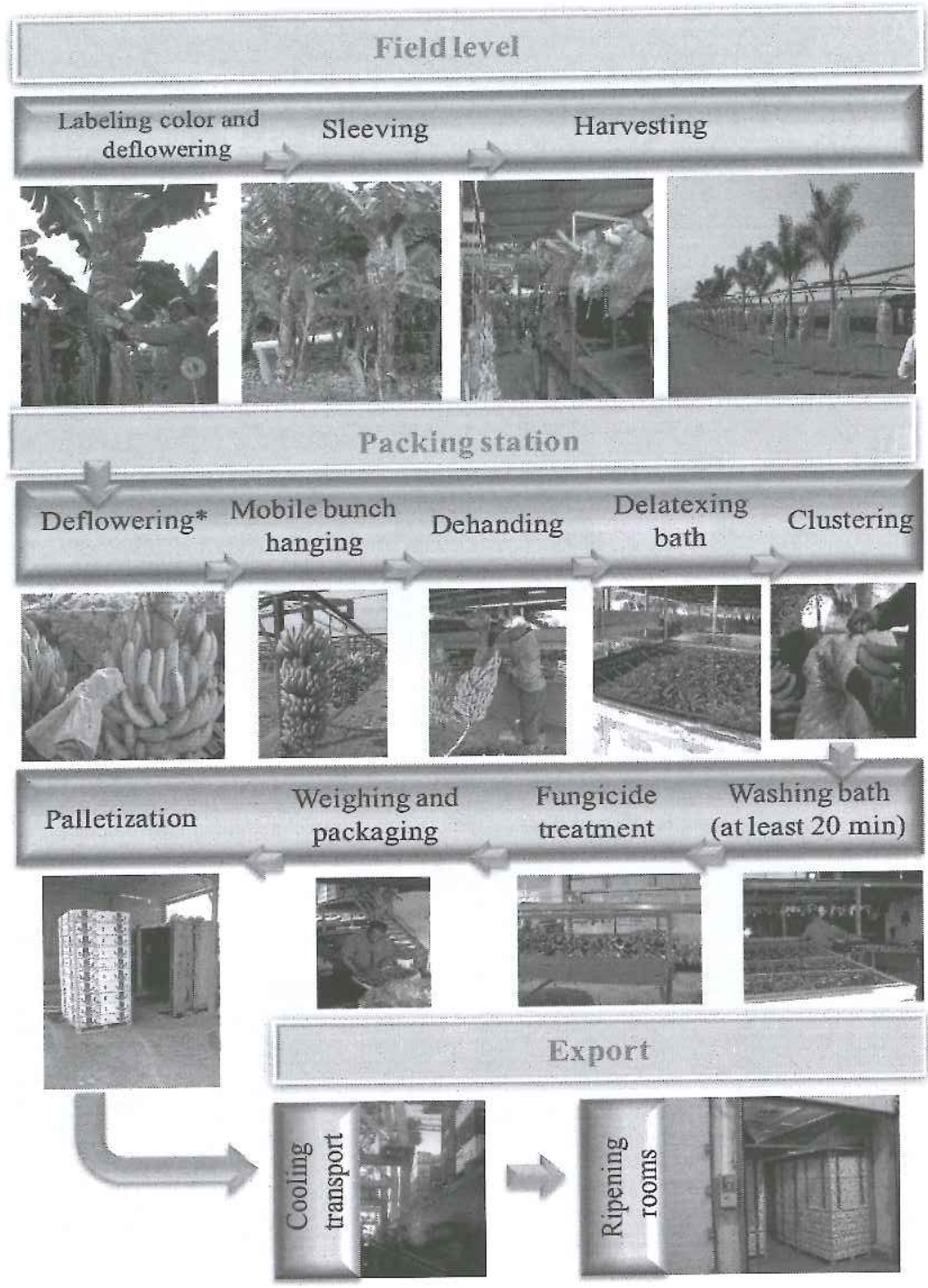

Figure 3.2 Successive operations carried out from the field to the banana marketing stage. *Deflowering is done in the packing station when it has not been done in the field (Lassois et al., 2010b).

into clusters consisting of several banana fruits joined by the crown tissues and boxed for shipping (Eckert and Ogawa, 1985). The crown became a prime site for infection by different pathogens (Lukezic et al., 1967; Griffee and Burden, 1976; Jones, 2000). 
The successive operations carried out from the field to the banana marketing stage are presented in Figure 3.2 and will help to a better understanding of the contamination process and the control methods.

\section{TAXONOMY AND MORPHOLOGY}

Crown rot is the result of the activity of a fungal complex. The role of bacteria in the complex has not been confirmed by detailed research (Lukezic et al., 1967). The microorganisms most commonly isolated in crown rot are: Musicillium theobromae, Colletotrichum musae, Ceratocystis paradoxa, Lasiodoplodia theobromae, Nigrospora sphaerica, Cladosporium spp., Acremonium spp., Penicillium spp. and Aspergillus spp., as well as many Fusarium species including F. semitectum, F verticillioides, Fs sporotrichoides, Foxysporum and F. solani (Greene and Goos, 1963; Lukezic et al., 1967; Wallbridge and Pinegar, 1975; Griffee and Burden, 1976; Shillingford, 1976; Wallbridge, 1981; Ogundero, 1987; Mesturino and Ragazzi, 1988; Johanson and Blasquez, 1992; Marin et al., 1996; Anthony et al., 2004). Several organisms may be involved in disease development, however, disease severity and the nature of the complex may vary substantially, depending on the production area and season (Table 3.1). Lukezic and Kaiser (1966) showed that fungal populations may differ between banana plants and even between clusters originating from the same plant.

Fungi of the complex do not all have the same pathogenicity and variations have been reported between regions. Knight (1982) considered that $F$ oxysporum, F. verticillioides and $F$ graminearum, which have been isolated frequently from crowns of Windward Island banana production, are primary pathogens, whereas $L$. theobromae, $M$. theobromae, and $N$. sphaerica are considered to be relatively non-pathogenic species. According to the findings of Marin et al. (1996) in Costa-Rica, F. verticillioides and F. semitectum are the most pathogenic species, while Griffee (1976) considered C. musae, L. theobromae, C. paradoxa, F. semitectum and F. graminearum as major pathogens involved in this disease in the Caribbean. However, many authors agree on the strong pathogenicity of C. musae, which may trigger an infection from a very small amount of inoculum since other pathogens require larger amounts of inoculum to induce crown rot symptoms (Greene and Goos, 1963; Lukezic et al., 1967; Griffee, 1976; Shillingford, 1976; Finlay and Brown, 1993; Krauss, 1996; Krauss et al., 1998; Lassois et al., 2008).

The nature of the complex, the specific pathogenicity of the different microorganisms involved as well as interactions among them may alter the 


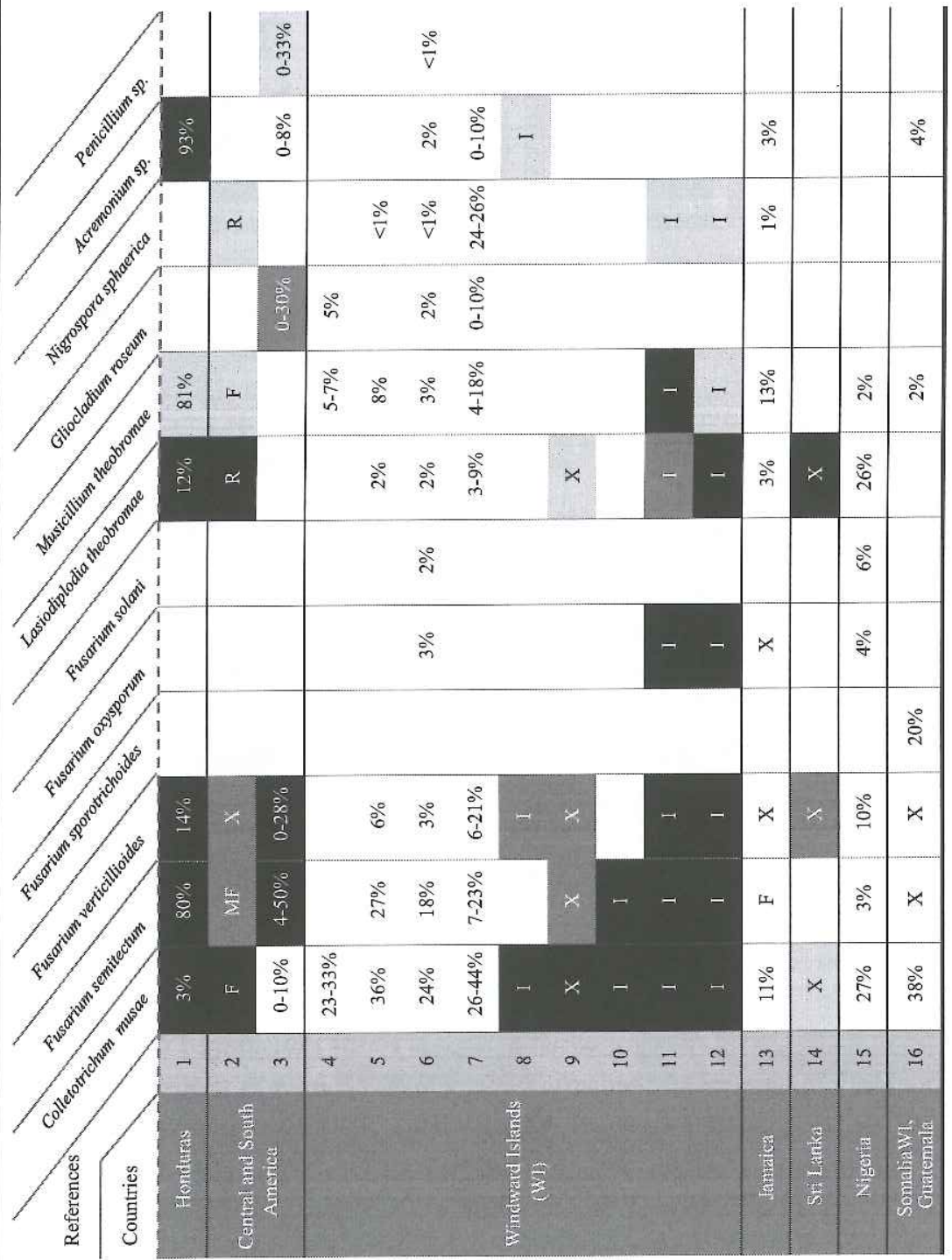

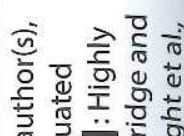

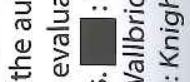
入े 닌 을 ऐं แ

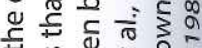

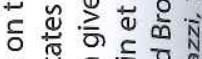
을 든 重 $\subseteq \frac{2}{3} \sum \pi$

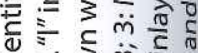

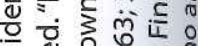
政 उ $\frac{\pi}{0}$ v

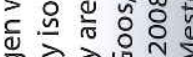

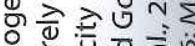
웜 范先茂 ○

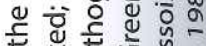
范 Æ ข추워 गै 을 을 $\subseteq$ Oㅁ

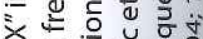

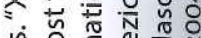

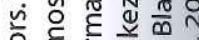

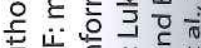

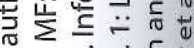

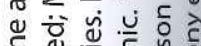

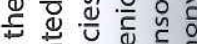
증 등 중

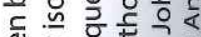

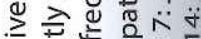
के टे ㄴ..ㄴ. ธ 둥의 उ北 ฯ

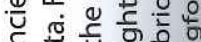

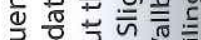
은 03 dै ठैं ᄃ ब둥

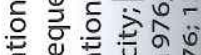

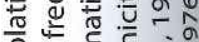
들 है वे 을 을 웡 은

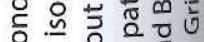
을르

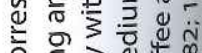

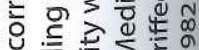

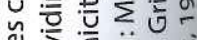
至 ग 잉 in

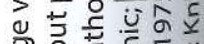

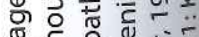

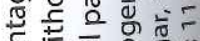

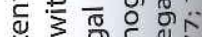

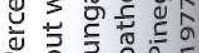


pathogenicity of the complex. Colletotrichum musae was more pathogenic when it was inoculated alone than when it was co-inoculated with other species (Lassois et al., 2008), however, Anthony et al. (2004) found that L. theobromae, F verticillioides, and C. musae were more highly pathogenic when co-inoculated than when they were inoculated separately.

The respective roles of the different species that could belong to the fungal complex have been thoroughly studied, whereas little information is available on the antagonistic or synergistic relationships among these different species.

More specifically, C. musae, the most pathogenic fungi associated with crown rot disease is a specific pathogen of banana. The genus Colletotrichum comprises imperfect fungi (Deuteromycetes) belonging to the order of Melanconiales. Colletotrichum musae is a distinct lineage in the 'gloeosporiodes' species complex (Su et al., 2011). The mycelium of C. musae is aerial, white turning an orange color with age (de Lapeyre de Bellaire, 1999;Abd-Elsalam et al., 2010). Conidia of C. musae are hyaline, non-septate, and mostly ellipsoid, ranging from $12-17 \mu \mathrm{m} \times 4-8 \mu \mathrm{m}$ in size (Lim et al., 2002; Abd-Elsalam et al., 2010) and are produced on septate conidiophores that are up to $30 \mu \mathrm{m}$ long and $3.5 \mu \mathrm{m}$ wide. Appressoria are highly melanized, dark brown and irregularly shaped ranging from $6-11 \times 5-10 \mu \mathrm{m}$ in size (de Lapeyre de Bellaire, 1999; Lim et al., 2002). Conidiophores are gathered within acervuli that are up to $400 \mu \mathrm{m}$ (Jones and Slabaugh, 1994). Colletotrichum musae produces its conidia in a mucilage which protects them and makes it possible to ensure their survival within acervuli (Mondal and Parbery, 2005).

\section{BIOLOGY OF CROWN ROT INFECTION PROCESS}

The large number of pathogens involved in the complex and the fact that the characteristics of each species differ complicates studies on the epidemic cycle and very little information is available on the epidemiology of the crown rot complex. Fruit contamination might occur in the field on the bunch or in the washing tanks in the packing station but, although field infections cannot be excluded, infections mainly occur during harvest when clusters are trimmed from bunches.

\section{Field Contamination}

\section{Conidial Dispersion}

Spores of some species, such as C. musae, are mainly disseminated by rainwater (Jeffries et al., 1990; de Lapeyre de Bellaire and Mourichon, 1997; de Lapeyre de Bellaire et al., 2000). Particularly, de Lapeyre de Bellaire et al. 
(2000) have shown that the streaming of rainwater is an essential factor for the transport of the conidia of C. musae on the surface of the fruit. Other banana pathogens are airborne and most species involved in the fungal complex are found in the air spora of a banana plantation (Meredith, 1962a), and it has also been shown that some Fusarium species can be wind disseminated (Lukezic and Kaiser, 1966).

\section{Fruit Contamination in the Field}

Fruit pollution and fruit contamination must be distinguished. Fruit pollution, which occurs in the field, concerns the quantity of conidia that reach the fruit surface. Fruit contamination is related to the quantity of conidia that infect the crown and leads to disease development. In banana plantations, fungal species sporulate abundantly on all putrescent organs such as leaves (Simmonds, 1941; Meredith, 1962a), floral parts (Agati, 1992; de Lapeyre de Bellaire and Mourichon, 1997), and bracts (Lukezic and Kaiser, 1966; de Lapeyre de Bellaire et al., 2000). Colletotrichum musae and some Fusarium species are primary colonizers of decomposing leaves (Meredith, 1962b) and floral parts (de Lapeyre de Bellaire et al., 2000). This fungus does not sporulate on the still green parts of the banana tree but only on the senescent organs. It develops as a saprophyte on all decomposition matter of the banana plantation. According to Meredith (1962b), C. musae is a primary colonizer of the decomposing leaves. This author explains that the infectious structures are formed on the leaves when they were still green, which confers a decisive advantage for the colonization of senescent organs. de Lapeyre de Bellaire and Mourichon (1997) have shown in a study carried out in Guadeloupe that the pollution of bananas by C. musae and various Fusarium species usually occurs during the first 40 days following bunch emergence and sharply decreases thereafter. For these authors, the floral parts and the last bunch bract are the two main effective sources of inoculum for the contamination of the fruits but, because they are closest to the fruit, the floral parts are the most effective inoculum source for fruit pollution.

\section{Fruit Contamination in the Packing Station}

The fungus C. musae, which is also the causal agent of anthracnose, establishes quiescent infections in the field during the first month following banana flowering (de Lapeyre de Bellaire et al., 2000). These quiescent infections could also contribute to the onset of crown rot if the pathogen has an opportunity to colonize the crown region (Griffee and Pinegar, 
1974). However, although field infections cannot be excluded, infections of the crown mainly occur during harvest and when clusters are trimmed from bunches (Meredith, 1971). Contamination generally takes place when hands are cut with a contaminated knife (Greene and Goos, 1963; Stover, 1972; Wallbridge, 1981; Finlay et al., 1992) or when clusters are cleaned with contaminated washing water (Shillingford, 1977) (see Fig. 3.2). At harvest, the fruit and senescent floral organs bear high quantities of spores that could potentially contaminate the crowns. Some of these spores could be removed by washing and then accumulate in the washing water (Slabaugh and Grove, 1982). The washing tanks are the main source of inocula according to Shillingford (1977). After the banana clusters are dipped in the washing water, the spores can passively penetrate a few millimeters into the vascular vessels of the crown, and disease is then hard to control with a fungicide spray treatment (Eckert and Ogawa, 1985). Greene and Goos (1963) have shown that a suspension of C. musae spores could penetrate $5-7 \mathrm{~mm}$ into the crown tissues within only $3 \mathrm{~min}$. Airborne spores may also contaminate the crowns before the fruit are placed in boxes in the packing station. The risk is especially high when the facilities are dirty or if debris (pistils, stalks, and fruits) is piled up nearby.

\section{PREHARVEST FACTORS FAVORING CROWN ROT DISEASE}

Most of the studies on crown rot focused on the etiology of the disease, especially on the identification of the most pathogenic fungal species involved, and on postharvest control methods. Unfortunately, these studies provided neither a good understanding of the conditions most conducive for disease expression nor adequate control of the disease at all spatio-temporal scales. There is now some evidence that fruit physiology at harvest influences crown rot development and that all interactions among the microorganisms implicated should be considered.Taking these into account, a new concept of 'banana quality potential at harvest' and a model of elaboration of this quality potential were proposed by Lassois et al. (2010b) (Fig. 3.3). In this model, the fruit quality potential at harvest is presented as a key factor in crown rot development. The quality potential develops during banana growth in the field and depends on two components: (1) a fruit physiological component, which determines the fruit susceptibility to the disease; and (2) a parasitic component that reflects a level of crown contamination by the fungal complex, as well as the pathogenicity of this complex. Both these components are major in 


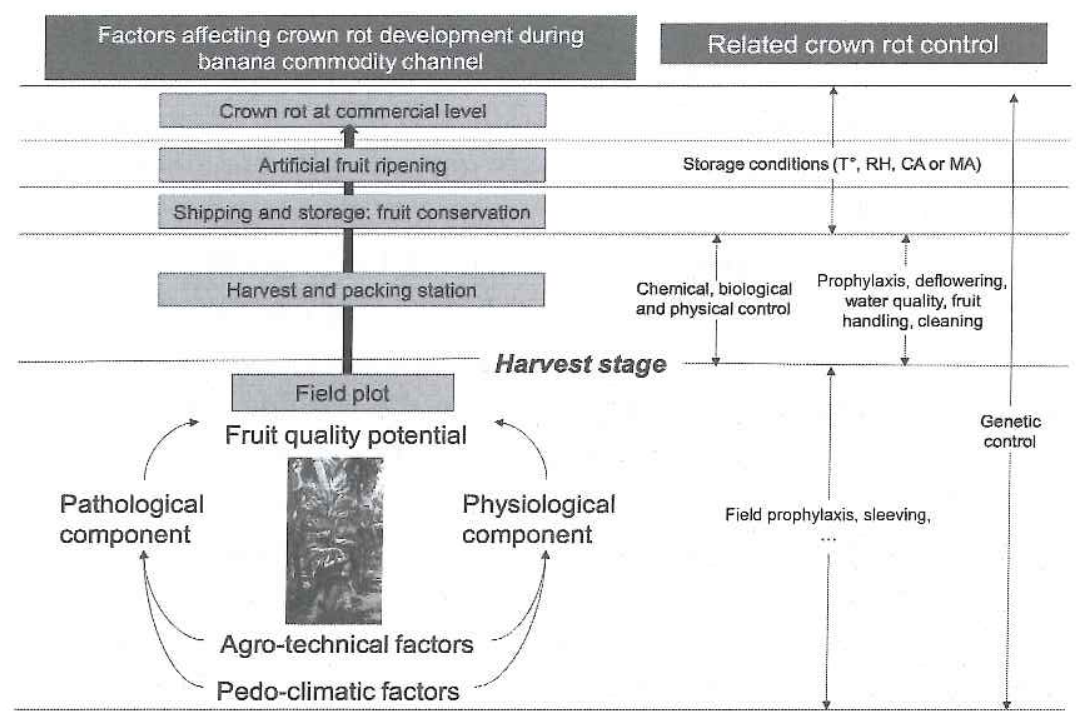

Figure 3.3 Diagram representing different key factors that arise throughout the commodity channel concerning crown rot development at commercial stage, and related control methods. $\mathrm{T}^{\circ}=$ temperature; $\mathrm{RH}=$ relative humidity; $\mathrm{CA}=$ controlled atmosphere; MA = modified atmosphere (Lassois et al., 2010b).

the postharvest development of the crown rot disease and are greatly influenced by all environmental and agrotechnical preharvest factors. Only a few studies link them to either fruit susceptibility or to fruit contamination, and these are presented hereafter.

\section{Influence of Environmental Factors on the Potential of Quality}

Geographical and seasonal variations have been observed in the incidence of crown rot disease of bananas (Lukezic et al., 1967; Shillingford, 1978; Krauss and Johanson, 2000). Lukezic et al. (1967) have shown that the incidence of this disease varied throughout the year in Honduras. It is generally higher during the summer (March to September) and declines during the coldest period (October to February). Moreover, in Jamaica, a high disease incidence was found to be correlated with periods during the year when temperatures were highest (Shillingford, 1978), whereas in the Windward Islands, the incidence was reported to be highest during the rainy period (Krauss and Johanson, 2000). Therefore, it was important to disentangle whether these spatio-temporal fluctuations affected the parasitic and/or the physiological component of the fruit quality potential. Some experiments were carried out through controlled inoculations and 
demonstrated that the spatio-temporal factors have an impact on the physiological component of the fruit quality potential. A multilocal study carried out in Cameroon over a 1-year period showed less crown rot development at higher altitude $(500 \mathrm{~m})$ than at lower altitude $(80 \mathrm{~m})$ (Ewanéet al., 2013b). This study also suggested that fruits harvested in a low-altitude plantation during the rainy season might be more susceptible to crown rot than those harvested during the dry season. On the other hand, continuous variations of fruit susceptibility have been shown in the same banana plot through studies realized in Cameroon (Lassois, et al., 2010a) and Guadeloupe (Lassois et al., 2008).

\section{Influence of Harvest Stage on Fruit Susceptibility}

Harvest stage is expressed in accumulated degree day (dd) (Jullien et al., 2008) from flowering to harvest. It has been shown that harvest stage affects fruit susceptibility to crown rot: (1) an intra-bunch susceptibility gradient has been documented with a linear correlation $(r=0.95)$ between the hand position on the bunch and crown rot development (Lassois, et al., 2010a). Clusters growing on the first hands of a bunch are, on average, $70 \mathrm{dd}$ more advanced than the hands initiated last (Jullien et al., 2001); (2) a linear relationship between fruit age (in dd) at harvest and the susceptibility of the fruit to crown rot was reported, with the oldest fruit being most susceptible to this disease (Forret, 2008).

\section{Influence of Source/Sink Ratio on Fruit Susceptibility}

Leaves are considered as 'source' tissues because they produce an excess of assimilates, while fruit are considered as 'sink' organs because they are not able to produce sufficient amounts of assimilate. It was demonstrated that the source/sink ratio during bunch growth affects the pomological characteristics of the fruits but also their susceptibility to crown rot (Lassois et al., 2010a). Fruits of bunches from which six hands were removed (high source/sink ratio, two hands remaining on the bunch) proved to be significantly less susceptible to crown rot than those from bunches with eight hands remaining on the bunch. It has also been shown that in the case of severe defoliations (low source-sink ratio), with only one or two leaves remaining on the tree, fruit susceptibility to crown rot disease was increased (Ewané, 2012). The authors considered that source/sink ratio modification leads, among other factors, to changes in the rate and characteristics of fruit filling which influences the formation of secondary metabolites involved in plant-pathogen interaction. A study was conducted to highlight underlying 
molecular mechanisms implied in the susceptibility variations observed when the source/sink ratio was modified (Lassois, et al., 2011a). Some genes involved in the susceptibility variation of bananas to crown rot disease were identified and results suggest that the catecholamine pathway could be implied in this phenomenon (Lassoiset al., 2011b). In the past, it had been suggested that preformed fungitoxic polyphenolic compounds could be involved in banana resistance to postharvest diseases (Mulvena et al., 1969; Muirhead and Deverall, 1984;Abdel-Saatar and Nawwar, 1986; Alam et al., 1993; Chillet et al., 2007), and it has also been shown that the modification of the source/sink ratio might induce modifications in the content of polyphenolics that might be implied in the modification of fruit susceptibility (Ewané, 2012).

\section{Effect of Some Biotic Factors on Fruit Susceptibility}

A study was carried out to evaluate the influence of some preharvest biotic factors on the fruits' susceptibility to postharvest crown rot development (Ewané et al., 2013a). It has been proven that the black leaf streak disease (Mycosphaerella fijiensis) severity at flowering and at harvest is positively correlated with the postharvest development of crown rot (Ewané et al., 2013a). This must be linked to the fact that black leaf streak disease reduces the source/sink ratio.

\section{Influence of Sanitation Practices on Fruit Contamination}

It is well known that most species involved in the fungal complex are saprophytes that occur on senescent banana organs, especially on decomposing leaves (Meredith, 1962b). Old leaves and other senescent organs present in the banana plantation may harbor inocula that could be responsible for severe contamination of bananas by this fungal complex (Simmonds and Mitchell, 1940).

\section{POSTHARVEST FACTORS FAVORING CROWN ROT DISEASE}

As can be seen in Figure 3.3, agronomic and environmental factors influence the fruit quality potential in the field and its propensity to develop crown rot. However, this figure also shows the importance of postharvest stages, such as harvesting, handling, transport and storage conditions in the development of crown rot. Fruit injuries enhance fruit ethylene production which has an impact on crown rot development. Furthermore, wounds on the fruits favor infection by pathogens. Fruit injuries must thus be avoided 
at all steps of the banana commodity channel. The inoculum pressure must be limited in all steps of the postharvest chain production to control efficiently crown rot development.

\section{Organization of the Banana Commodity Channel}

Due to the highly perishable nature of banana fruit, the commodity channel has to be well organized at all levels (Krauss and Johanson, 2000). This includes timely harvesting, a rapid cooling of fruit which is a prerequisite for effective crown rot control, an effective 'in' and 'out' quality control, an integrated efficient postharvest crown rot control, rapid loading into the boats and a continuous cooling chain from the beginning of the voyage to ripening centers and retailers in the importation countries. Shortcomings here can negate other efforts made to maintain healthy fruits.

It is difficult to control most of the preharvest factors in order to reduce crown rot impact. Inversely, most of the postharvest factors have to be controlled to reduce crown rot disease development. The impact of these different stages on disease development, as well as the methods applied to limit them, will be described in the following section concerning postharvest control methods.

\section{CONTROL METHODS AND ALTERNATIVES TO CHEMICAL CONTROL}

\section{Conventional Chemical Control}

Banana crown rot, like other storage diseases, has an especially detrimental impact on export produce. Routine postharvest fungicide treatment is still the most efficient and used crown rot control method (Table 3.2). This strategy was introduced in the late 1960 s with the discovery of systemic benzimidazole derivative fungicides (thiabendazole and benomyl). They are classified as antimitotic compounds. Gradually, other fungicides that inhibit ergosterol biosynthesis, such as imazalil and bitertanol, were also introduced (Frossard et al., 1977; de Lapeyre de Bellaire and Nolin, 1994). The recent exclusion of bitertanol led to the use of QoI fungicides like azoxystrobin. The application methods vary markedly, including dipping, spraying and cascade treatment (see Fig. 3.2) but, in every case, the bananas must be thoroughly wetted to ensure fungicide treatment efficacy (de Lapeyre de Bellaire and Nolin, 1994). Alum is often combined with fungicide slurries to neutralize latex residue remaining on crowns when the bananas are removed 
Table 3.2 Summary of Different Fungicides Used for Controlling Postharvest Diseases of Bananas in Commercial Banana Plantations.

\begin{tabular}{|c|c|c|c|c|}
\hline $\begin{array}{l}\text { Active } \\
\text { Ingredient }\end{array}$ & $\begin{array}{l}\text { Mode of } \\
\text { Action }\end{array}$ & $\begin{array}{l}\text { Recommended } \\
\text { Rate }\left(\mathrm{mg} \mathrm{L}^{-1}\right)\end{array}$ & $\begin{array}{l}\text { Commercial } \\
\text { Name }\end{array}$ & Observations \\
\hline Benomyl & antimicotic & 250 & Benlate $(\AA$ & Banned \\
\hline Thiabendazole & antimicotic & 450 & 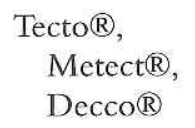 & $\begin{array}{l}\text { Efficient on } \\
\text { crown rot and } \\
\text { anthracnose }\end{array}$ \\
\hline Imazalil & $\begin{array}{l}\text { ergosterol } \\
\text { biosynthesis } \\
\text { inhibitor } \\
\text { (DMI) }\end{array}$ & 375 & $\begin{array}{c}\text { Fungaflor }(\text {, } \\
\text { Sulima }( \\
\text { Neozil }\end{array}$ & $\begin{array}{l}\text { Effective on } \\
\text { crown rot, } \\
\text { not on } \\
\text { anthranose }\end{array}$ \\
\hline Bitertanol & $\begin{array}{l}\text { ergosterol } \\
\text { biosynthesis } \\
\text { inhibitor } \\
\text { (DMI) }\end{array}$ & 200 & Baycor $(\mathbb{R})$ & $\begin{array}{l}\text { Efficient on } \\
\text { crown rot and } \\
\text { anthracnose. } \\
\text { Recently } \\
\text { banned }\end{array}$ \\
\hline Azoxystrobin & $\begin{array}{l}\text { Quinone } \\
\text { oustside } \\
\text { inhibitor } \\
\text { (QoI) }\end{array}$ & 60 & $\begin{array}{l}\text { Ortiva }(\mathbb{R}, \\
\text { Bankit }(\mathbb{R})\end{array}$ & $\begin{array}{l}\text { Efficient on } \\
\text { crown rot and } \\
\text { anthracnose }\end{array}$ \\
\hline
\end{tabular}

from the washing bath (Muirhead and Jones, 2000), however, this mixture seems to have a negative impact on the performance of some active ingredients such as thiabendazole (Joas and Malisart, 2001). The time between crown trimming and fungicide application is critical. Crown rot severity seems to increase when fungicide application is delayed (Greene and Goos, 1963). Bananas are, nevertheless, usually treated in time in packing stations, i.e. just after they are removed from the washing bath. Problems concerning the development of resistant strains may arise with this practice. Postharvest fungicides generally have the same mode of action as those sprayed in the field to control Sigatoka disease. Colletotrichum musae strains resistant to thiabendazole, and generally to all antimitotic compounds, have been detected in many banana-producing countries (Hostachy et al., 1990; Johanson and Blasquez, 1992; de Lapeyre de Bellaire and Dubois, 1997; Krauss and Johanson, 2000). In Guadeloupe, it has been shown that thiabendazole-resistant C. musae strains developed after exclusive foliar applications of benomyl over a decade (1972-1982) for Sigatoka disease control (de Lapeyre de Bellaire and Dubois, 1997). Postharvest use of chemicals could ultimately be prohibited because the number of active substances registered for postharvest treatment has been reduced by current regulations, and legislation is 
becoming increasingly restrictive. Moreover, the efficacy of intensive fungicide treatments is not always adequate. In some areas where very few resistant strains are present, the efficacy of fungicides for postharvest disease control was found to vary substantially depending on season and production area (Chillet and de Lapeyre de Bellaire, 1996). Finally, consumers are now highly selective with respect to food safety concerns, and demand is increasing for produce that has not undergone any postharvest chemical treatments. Alternative non-fungicide solutions are therefore being sought.

\section{Non-Conventional Control}

Because the systematic fungicide control approach is not satisfactory and is increasingly criticized, several biological control approaches have been developed in recent years to find alternatives. We present here a set of methods that should be implemented in an integrated way to achieve efficient crown rot control (see Fig. 3.3) as an alternative to chemical control.

\section{Field Control Methods}

\section{Bunch Sanitation}

- Leaf removal:since senescent leaves hanging on the bunch might enhance fruit contamination (Meredith, 1962b; de Lapeyre de Bellaire et al., 2000), these leaves must be removed to reduce fruit contamination.

- Bunch sleeving (see Fig. 3.2): no accurate studies have been carried out to assess the impact of sleeving on crown rot development rate. It is, nevertheless, known that bunch sleeving with perforated plastic film protects bunches from fungal contamination and can reduce contamination by C. musae by over $80 \%$ (de Lapeyre de Bellaire et al., 2000). These results suggest that sleeving directly reduces crown contamination in the field, or that sleeved fruits release fewer spores in washing water during packing operations. Furthermore, this practice protects fruits from injuries.

- Deflowering (see Fig. 3.2): the main inoculum sources for C. musae and several Fusarium species are the floral remnants of the fruits and their early removal, generally when the young hands assume a horizontal position, is an important step further to limit bunch contamination (de Lapeyre de Bellaire et al., 2000).

\section{Controlling the Banana Harvest Stage}

Bananas are climacteric fruits, and the period between harvest and climacteric, the preclimacteric life, is commonly called the green life. 
Bananas should be harvested at an age that will ensure a sufficient preclimacteric life during husbandry, because they should reach the ripening rooms still unripe (green). Furthermore, bananas are exported to Europe when they have grown to a commercial grade specified by European regulations (Commission Regulation (EC) No 2257/94 of 16 September 1994, setting quality standards for bananas) and market requirements. Thus, both age and grade of bananas are closely monitored during bunch development to determine the optimum date for harvest. Generally, once a week, newly emerged bunches are tagged with a colored plastic ribbon; different colors correspond to different weeks. Based on this colored system, the age of the banana is either estimated (1) in days or (2) in physiological age of the fruits.This age is then expressed as a sum of accumulated temperatures from flowering to harvest rather than in days (Jullien et al., 2008). It has been shown that physiological age is the best estimator of the green life. It has also been shown that younger fruits are less susceptible to crown rot than older fruits of the same grade (Forret, 2008), so good harvest stage management is an essential step to reduce harvesting of very susceptible fruits.

\section{Black Leaf Streak Control}

Good control of black leaf streak (Ewané et al., 2013a) or other foliar disease is important, since these disease promote fruit crown rot susceptibility by reducing the source/sink ratio. This requires proper chemical strategies as well as other integrated practices (de Lapeyre de Bellaire et al., 2010).

\section{Genetic Control}

The range of varieties grown for dessert banana export is very narrow as all clones belong to the Cavendish subgroup (Bakry et al., 1997). Moreover, breeding is complicated because triploid banana varieties are generally sterile. In the past, banana genetic improvement programs were mainly focused on obtaining varieties resistant to Sigatoka and Panama diseases. Resistance to crown rot of improved varieties has not been considered in any breeding programs to date. According to Marin et al. (1996), FHIA-01 and FHIA-02, two hybrids produced by the FHIA breeding program, are partially resistant to crown rot. Conversely, Perez-Vicente and Hernandez (2002) consider that these two varieties are more susceptible to crown rot caused by $F$. semitectum and C. musae compared with Cavendish varieties. According to these authors, only FHIA-23 is more resistant to crown rot than Grande-Naine. Finally, the first FHIA hybrids were introduced in the late 1980s, but their characteristics 
differ from those of Cavendish bananas and consumers have shown little interest in them, thus limiting their distribution.

\section{Postharvest Control Methods}

\section{Deflowering and Sanitization}

Deflowering involves the removal of all floral parts that could potentially harbor inocula before the dehanding operation (see Fig. 3.2). When the floral parts have not been removed in the field, deflowering is done in the packing station before bunch trimming, thus reducing the risk of contamination of the washing baths (Shillingford, 1976; Krauss and Johanson, 2000).

\section{Packing Station Water Quality}

Contamination of crowns when the bananas are processed in the dehanding and washing tanks is a key step in crown rot development because the wounds resulting from the clustering of banana hands are the main portal for infection by crown rot pathogens. Spore accumulation in the water can be reduced by regularly changing the washing water in the washing and delatexing baths (Slabaugh and Grove, 1982). These baths can contain a high quantity of spores, mainly Fusarium spp. and Verticillum spp., that detach from the peel surface (Shillingford, 1977), whereas C. musae conidia are less often found (Shillingford, 1976). Care should be taken to avoid contaminating the baths with plant debris (pistils, leaves, trimming waste, etc.) and the water should be regularly refreshed.

It is also recommended that the bath water be treated with active chlorine at the rate of 1-2 $\mathrm{mg} \mathrm{L}^{-1}$ (Arneson, 1971; Slabaugh and Grove, 1982; Eckert and Ogawa, 1985) or quaternary ammonium disinfectants in order to hamper contamination (Shillingford, 1977), but the efficacy of this disinfection procedure is controversial (Slabaugh and Grove, 1982; Eckert and Ogawa, 1985). The chlorine concentration should be regularly adjusted to offset the high observed losses by volatilization or through redox reactions with latex or other organic matter in the washing baths (Shillingford, 1977).

\section{Packing Station Sanitation}

Protective measures implemented in the packing station are aimed at keeping the crowns of freshly trimmed bananas away from all inoculum sources. To ensure efficient crown rot control, it is thus essential to keep the packing station and the adjoining facilities clean. Waste (stalks, low-grade fruit, etc.) located in the vicinity of the banana packing area, which could contaminate the air in the station, must be eliminated (Finlay et al., 1992; Krauss and 
Johanson, 2000). It has been shown that trimming clusters in a clean environment rather than in the field can reduce crown rot incidence by $50 \%$.

\section{Banana and Crown Trimming}

The fruits should also be cleaned before being trimmed from the bunch. A contaminated trimming knife could spread inocula from the peel into the crown tissues (Lukezic et al., 1967). This may be avoided by washing the bunches in chlorinated water before they are trimmed into clusters (Krauss and Johanson, 2000). Bananas should be trimmed with a clean stainless steel blade. It was shown that roughly trimming the crowns, or ripping them off the hands, significantly increased the level of crown rot disease. Tissue fragments on the surface of the crowns dry out and quickly become senescent, thus providing an ideal site for rot development. Moreover, banana trimming knife tips are rounded to avoid banana fruit wounds. It is also important to cut wide crown sections containing as much crown tissue as possible, a technique that seems to enhance crown resistance to rot and seldom leads to the spread of rot into the fruit pedicels (Muirhead and Jones, 2000).

\section{Packing}

Although most pathogens require a high relative humidity for their in vitro development (Badger, 1965), bananas are less susceptible to crown rot under these conditions. A high relative humidity seems to hinder transpiratory water loss from the fruit, which is essential to ensure a long green life. Indeed, this ripening stage is markedly reduced under low relative humidity atmospheric conditions (30-40\%) as a result of ethylene production from the fruit peel (Peacock, 1973). The senescence of banana crown tissues can then be hampered by maintaining their turgidity in plastic bag packaging (Muirhead and Jones, 2000).

\section{Shipping}

Bananas must be cooled as soon as possible to $13^{\circ} \mathrm{C}$ after packing and delivered promptly to a ripening facility (see Fig. 3.2). One way to slow down banana metabolism, and thus to delay crown rot development, is to refrigerate the fruit in boxes at the lowest possible temperature without inducing physiological disorders. Cooling should be continuous throughout the shipping phase which, in turn, should be as short as possible. Containers designed for maritime shipping of bananas are climate controlled at $13-14^{\circ} \mathrm{C}$, because temperatures below $12^{\circ} \mathrm{C}$ provoke peel browning due to oxidization (Muirhead and Jones, 2000). Fungal growth is slowed down at $13^{\circ} \mathrm{C}$ (Finlay 
and Brown, 1993) which is a good trade-off with respect to preserving the bananas and hampering fungal colonization of the crowns. However, this is much lower than the optimal temperatures for germination and growth of fungi responsible for crown rot, but it is not low enough to slow down the activity of these fungi, which can take place within a broad temperature range, i.e. $8-36^{\circ} \mathrm{C}$ (Simmonds and Mitchell, 1940). As a result, crown rot incidence and severity are higher in bananas exposed to temperatures over $16^{\circ} \mathrm{C}$ (Slabaugh and Grove, 1982).

\section{Controlled and Modified Atmospheres}

The composition of the atmosphere around bananas during shipping can be manipulated to slow down metabolic activity. Moreover, high $\mathrm{CO}_{2}(>15 \%)$ and low $\mathrm{O}_{2}(<1 \%)$ levels are toxic to many fungi (Goos and Tschirsch, 1962; Al Zaemey et al., 1994). Unfortunately, bananas cannot be stored under these conditions because major physiologic alterations generally occur during ripening when the atmospheric $\mathrm{CO}_{2}$ level is above $7-12 \%$ or when the $\mathrm{O}_{2}$ level is below 1-2\% (Daun et al., 1973; Wilson, 1976; Thompson, 1998). Then, ideally, bananas should be stored in an atmosphere of $5-7 \% \mathrm{CO}_{2}$ and $2 \% \mathrm{O}_{2}$ (Daun et al., 1973; Thompson, 1998). Modified atmospheres (MA) can be achieved by packing bananas in sealed plastic bags (polybags), and controlled atmospheres (CA) are obtained by injecting pure nitrogen into the storage rooms. It was shown that crown rot can be partially controlled (20\%) by packing bananas in $\mathrm{MA}\left(1-2 \% \mathrm{O}_{2}\right.$ and $\left.12-14 \% \mathrm{CO}_{2}\right)$ (Bastiaanse et al., 2010). For $\mathrm{MA}$, the balance of $\mathrm{O}_{2}$ and $\mathrm{CO}_{2}$ contents depends on the extent of fruit respiration, bag permeability, and the composition of the air outside the bag (Thompson, 1998). The $\mathrm{O}_{2}$ and $\mathrm{CO}_{2}$ contents generally range from 1 to $10 \%$ and 2 to $14 \%$, respectively, depending on the quality and thickness of the plastic packaging (Marriott and Palmer, 1980; Thompson, 1998). These plastic bags must also have a high mechanical strength because even small punctures will upset the MA (Chillet and de Lapeyre de Bellaire, 1996).

\section{Hot Water Treatments (HWT)}

To date, there has been no commercial adaptation of this technique to bananas grown for exportation (Cavendish), like in other tropical fruits such as papaya (Couey et al., 1984; Nishijima et al., 1992) and mango (Spalding and Reeder, 1978; Coates et al., 1993). However, some recent work has been done on local cultivars grown in Asian countries. Hot water treatment $\left(20 \mathrm{~min}\right.$ at $50^{\circ} \mathrm{C}$ ) is ineffective in killing dormant spores but causes a delay 
in mycelium growth and conidial germination on cv 'Bungulan'(AAA) grown in the Philippines (Alvindia, 2012). De Costa and Erabadupitiya (2005) have shown that the optimal temperature and exposure time for controlling crown rot on 'Embon' (AAA) and 'Kolikuttu' (AAB) varieties from Sri Lanka was $50^{\circ} \mathrm{C}$ for $3 \mathrm{~min}$. Higher temperatures lead to pale fruit, and exposure times of over $5 \mathrm{~min}$ reduce Brix values (De Costa and Erabadupitiya, 2005) and caused unacceptable fruit browning on cv 'KluaiHom Thong' (AAA) from Thailand (Win et al., 2007). In Brazil, a 20 min longer treatment at a temperature under $45^{\circ} \mathrm{C}$ was effective for crown rot control in cv 'Santa CatarinaPrata' (AAB) and 'Williams' (Cavendish, AAA) with the percentage of infected bananas decreasing from $100 \%$ to less than $15 \%$ (Reyes et al., 1998). However, commercial tests on naturally infected fruit have not achieved crown rot control, and ripening delays have also been noted.

\section{UV and Gamma Radiation Treatment}

Ultraviolet light (UV) treatments have considerable potential for fruit and vegetable postharvest disease control. Stevens et al. (2005) discussed the possibility of inducing apple resistance to C. gloeosporioides through UV-C treatments. In bananas, however, the peel seems to be too sensitive to UV for the use of this technique for postharvest control of some pathogens of the complex of C. musae (Joas, 1997).

Kanapathipillai et al. (1987) pointed out that gamma ray treatment (38 min at $4 \mathrm{kGy}$ ) inhibited spore germination, the formation of C. musae appressoria, and all fungal development on the surface of fruit pieces. However, these authors did not investigate the effects of gamma rays on whole fruit, or on their complex components. Although dosages of around $0.5 \mathrm{kGy}$ can extend banana green life (Marriott and Palmer, 1980; Wills et al., 1998), Marriott and Palmer (1980) noted that irradiation can alter the banana peel; the maximum dose tolerated by the fruits is likely around $0.5 \mathrm{kGy}$ (Wills et al., 1998). Finally, the development of postharvest fruit irradiation has been hampered especially by the high cost of such treatments and their low consumer acceptance.

\section{Biological Control}

Currently, there is a continuation of a study on developing a biocontrol formulation to treat crown rot of banana and to replace the systematic fungicide treatment. The following examples are far from exhaustive. Postharvest biological control is very promising because the crown rot infection site 
on the fruit is limited, the environmental conditions during storage are clearly defined and stable, and bananas have a high added value (Jijakli and Lepoivre, 1999). The results of many studies have suggested that the use of microorganisms such as fungi, bacteria, and yeasts could provide partial crown rot control (Postmaster et al., 1997; De Costa and Subasinghe, 1998; East and Kenyon, 1998; Krauss et al., 1998; Gunasinghe et al., 2004; De Costa and Erabadupitiya, 2005; Alvindia and Natsuaki, 2008; Lassois et al., 2008; Williamson et al., 2008; Sangeetha et al., 2010a). It has also been shown that biological control efficacy increases with the antagonistic agent concentration and with the incubation time between the application of the antagonist and crown contamination by the fungal complex (Postmaster et al., 1997; Lassois et al., 2008). Antagonists can be used to reduce significantly lesions induced by the fungal complex that causes crown rot, but the control efficacy is limited and variable (Lassois et al., 2008). This type of control, when used alone, cannot provide total crown rot control, and so should be combined with other control tactics such as inorganic salts and MA packaging to improve the effectiveness (Bastiaanse et al., 2010; De Costa and Gunawardhana, 2012; Alvindia, 2013).

\section{Natural Compounds}

The impact of several natural substances or non-synthetic fungicides, such as preparations of calcium, plant extracts or organic acids, on crown rot development has also been evaluated. Garlic (Allium sativum) extracts (Krauss and Johanson, 2000) and essential oils of cinnamon (Cinnamomum zeylanicum), clove (Syzygium aromaticum) (Ranasinghe et al., 2002, 2005), citronella (Cymbopogon nardus), and basil (Ocimum basilicum) (Anthony et al., 2004; Sangeetha et al., 2010b) have also been found to have fungicidal activity. Win et al. (2007) showed that cinnamon extracts $\left(5 \mathrm{~g} \mathrm{~L}^{-1)}\right.$ partially reduced crown rot severity (25\%), increased green life, and had no negative effects on postharvest banana quality. These plant extracts have fungistatic and fungitoxic activity and can inhibit completely conidial germination and mycelial growth of C. musae, Fusarium spp., and L. theobromae. However, cases of phytotoxicity have been reported and the level of control provided by these natural substances is not sufficient to meet market requirements. The use of antioxidants (Khan et al., 2001) and organic salts (Alvindia et al., 2004), sometimes combined with surfactants (Alvindia and Natsuaki, 2007), can also enable partial crown rot control (up to 60\%). Finally, experiments showed that some treatments were found to provide the same level of crown rot control as fungicide treatment (Alvindia, 2013; Sangeetha et al., 2013). 
This is the case with Biocto 6 (seed extract from citrus) (Productos Biogenicos S.A., San Jose, Costa Rica) combined with a wax-based additive (Verdiol, Productos Biogenicos S.A., San Jose, Costa Rica) (Demerutis et al., 2008). In the same way, Sangeetha et al. (2013) showed that the dipping of banana in zimmu leaf extract at $25 \%$ concentration exhibited $100 \%$ inhibition of crown rot disease in cold storage $\left(14^{\circ} \mathrm{C}\right)$ up to 35 days and increased the shelf-life to 64 days without altering organoleptic properties. These seem to be a promising potential ecofriendly technology substituting fungicides in the control of the disease but further studies would be needed prior to recommending them in commercial packing houses, including validation of the results in real full-scale commercial exportation conditions, identification of the principle compounds responsible for the control and also the performance of safety tests.

\section{CONCLUDING REMARKS}

Crown rot studies and control are especially complex because of the observed diversity and variability in the composition and pathogenicity of the complex involved in the development of this disease. The broad range of possible situations complicates studies on both the parasitic and physiologic components of fruit quality. Further studies are thus required to gain better insight into this disease, especially because little documentation is available on certain aspects such as the epidemiology of crown rot. It is also very important to enhance the overall understanding of banana physiological mechanisms involved in the induction of fruit resistance to crown rot pathogens with the aim of improving control.

There is considerable growing interest in alternative methods to reduce or even completely eliminate fungicide treatments. To be efficient, these alternative control methods should not be too specific considering the broad spectrum of pathogens involved in the complex. Crown rot research should enhance the overall understanding of this disease and thus lead to the development of an effective integrated control strategy.

\section{REFERENCES}

Abd-Elsalam, K.A., Roshdy, S., Amin, O.E., Rabani, M., 2010. First morphogenetic identification of the fungal pathogen Colletotrichum musae (Phyllachoraceae) from imported bananas in Saudi Arabia. Genet. Mol. Res. 9, 2335-2342.

Abdel-Saatar, M., Nawwar, M., 1986.3,4-dimethoxybenzaldehyde, a fungistatic substance in peel of green banana fruits in relation to resistance at different degrees of maturity. Horticultural Science 21,812. 
Agati, J.A., 1992. Banana stem and fruit rot. Philippine Agric. 10, 411-422.

Al Zaemey, A.B., Magan, N., Thompson, A.K., 1994. In vitro studies of the effect of environmental conditions on the anthracnose pathogen of bananas, Colletotrichum musae. Int. Biodeterioration Biodegradation 33, 369-381.

Alam, M.S., Alam, S., Islam, S., Alam, N., 1993. Biochemical changes in banana fruits in response to crown rot pathogens. Bangladesh J. Bot. 22, 143-148.

Alvindia, D.G., 2012. Revisiting hot water treatments in controlling crown rot of banana cv. Buñgulan. Crop Prot. 33, 59-64.

Alvindia, D.G., 2013. Enhancing the bioefficacy of Bacillus amyloliquefaciens DGA14 with inorganic salts for the control of banana crown rot. Crop Prot. 51, 1-6.

Alvindia, D.G., Kobayashi, T., Natsuaki Keiko, T., Tanda, S., 2004. Inhibitory influence of inorganic salts on banana postharvest pathogens and preliminary application to control crown rot. J. Gen. Plant Pathol. 70, 61-65.

Alvindia, D.G., Kobayashi, T., Yaguchi,Y., Natsuaki, K. T., 2000. Symptoms and the associated fungi of postharvest diseases on non-chemical bananas imported from the Philippines. Japanese J.Trop. Agric. 44, 87-93.

Alvindia, D.G., Natsuaki, K.T., 2007. Control of crown rot-causing fungal pathogens of banana by inorganic salts and a surfactant. Crop Prot. 26, 1667-1673.

Alvindia, D.G., Natsuaki, K.T., 2008. Evaluation of fungal epiphytes isolated from banana fruit surfaces for biocontrol of banana crown rot disease. Crop Prot. 27, 1200-1207.

Anthony, S., Abeywickrama, K., Dayananda, R., Wijeratnam Shanthi, W., Arambewela, L., 2004. Fungal pathogens associated with banana fruit in Sri Lanka, and their treatment with essential oils. Mycopathologia 157, 91-97.

Arneson, P.A., 1971. Sensitivity of postharvet rot fungi of bananas to chlorine. Phytopathology 61, 344-345.

Badger, A.M., 1965. Influence of relative humidity on fungi causing crown rot of boxed bananas. Phytopathology 55, 688-692.

Bakry, F., Carreel, F., Caruana, M.L., Côte, F.X., Jenny, C., Tezenas du Montcel, H., 1997. Les bananiers. In: Charrier, A., Hamon, S., Jacquot, M., Nicolas, D. (Eds.), L'amélioration des plantes tropicales. CIRAD ORSTOM, Montpellier, pp. 109-139.

Bastiaanse, H., de Lapeyre de Bellaire, L., Lassois, L., Misson, C., Jijakli, M.H., 2010. Integrated control of crown rot of banana with Candida oleophila strain $\mathrm{O}$, calcium chloride and modified atmosphere packaging. Biol. Control 53, 100-107.

Chillet, M., de Lapeyre de Bellaire, L., 1996. Conditionnement en polybag pour le contrôle de l'anthracnose de blessure des bananes. Fruits 51, 163-172.

Chillet, M., Hubert, O., de Lapeyre de Bellaire, L., 2007. Relationship between physiological age, ripening and susceptibility of banana to wound anthracnose. Crop Prot. 26, 1078-1082.

Coates, L.M., Johnson, G.I., Cooke,A.W., 1993. Postharvest disease control in mangoes using high humidity hot air and fungicide treatments. Ann. Appl. Biol. 123, 441-448.

Couey, H.M., Alvarez, A.M., Nelson, M.G., 1984. Comparison of hot-water spray and immersion treatments for control of pstharvest decay of papaya. Plant Dis. 68, 436-437.

Daun, H., Gilbert, S.G., Ashkenazi, Y., Henig, Y., 1973. Storage quality of bananas packaged in selected permeability films. J. Food Sci. 38, 1247-1250.

Daundasekera, M., Joyce, D.C., Aked, J., Adikaram, N.K.B., 2003. Ethylene production by Colletotrichum musae in vitro. Physiol. Mol. Plant Pathol. 62, 21-28.

De Costa, D.M., Erabadupitiya, H.R.U.T., 2005. An integrated method to control postharvest diseases of banana using a member of the Burkholderia cepacia complex. Postharvest Biol. Technol. 36, 31-39.

De Costa, D.M., Gunawardhana, H.M.D.M., 2012. Effects of sodium bicarbonate on pathogenicity of Colletotrichum musae and potential for controlling postharvest diseases of banana. Postharvest Biol. Technol. 68, 54-63. 
De Costa, D.M., Subasinghe, S.S.N.S., 1998. Antagonistic bacteria associated with the fruit skin of banana in controlling its post-harvest diseases. Trop. Sci. 38, 206-212.

de Lapeyre de Bellaire, L., 1999. Bio-écologie de Colletotrichum musae (Berk. \& Curt.) Arx, agent de l'anthracnose des bananes, dans les conditions tropicales humides de la Guadeloupe. Université de Paris-Sud, Orsay. p. 100.

de Lapeyre de Bellaire, L., Chillet, M., Dubois, C., Mourichon, X., 2000. Importance of different sources of inoculum and dispersal methods of conidia of Colletotrichum musae, the causal agent of banana anthracnose, for fruit contamination. Plant Pathol. 49, 782-790.

de Lapeyre de Bellaire, L., Dubois, C., 1997. Distribution of thiabendazole-resistant Colletotrichum isolates from Guadeloupe banana plantations. Plant Dis. 81, 1378-1383.

de Lapeyre de Bellaire, L., Fouré, E., Abadie, C., Carlier, J., 2010. Black leaf streak disease is challenging the banana industry. Fruits $65,327-342$.

de Lapeyre de Bellaire, L., Mourichon, X., 1997. The pattern of fungal contamination of the banana bunch during its development and potential influence on incidence of crownrot and anthracnose diseases. Plant Pathol. 46, 481-489.

de Lapeyre de Bellaire, L., Nolin, J., 1994. Amélioration du contrôle du chancre sur les bananes d'exportation et traitements post-récolte. Fruits 49, 179-185.

Demerutis, C., Quirós, L., Martinuz, A., Alvarado, E., Williams, R.N., Ellis, M.A., 2008. Evaluation of an organic treatment for post-harvest control of crown rot of banana. Ecol. Eng. 34, 324-327.

Dominguez, M., Vendrell, M., 1993. Wound ethylene biosynthesis in preclimacteric banana slices. Acta Horticulturae 343, 270-274.

East, L., Kenyon, L., 1998. Development of biological control methods for post-harvest rots of banana. In: Council, B.C.P. (Ed.), Proceedings of the Brighton Crop Protection Conference: Pests and Diseases. United Kingdom edn. Farnham (United Kingdom), Brighton, UK, pp. 549-554. 16-19, November 1998.

Eckert, J.W., Ogawa, J.M., 1985. The chemical control of post-harvest diseases: subtropical and tropical fruits. Ann. Rev. Phytopathol. 23, 421-454.

Ewané, C.A., 2012. Etude de la composante physiologique impliquée dans le développement des pourritures de couronne de bananes et rôle des composés phénoliques dans les mécanismes de variation de sensibilité. Ph D thesis. Plant pathology Unit, Gembloux Agro-Bio Tech.

Ewané, C.A., Chillet, M., Castelan, F., et al., 2013a. Impact of the extension of black leaf streak disease on banana susceptibility to post-harvest diseases. Fruits $68,351-365$.

Ewané, C.A., Lassois, L., Brostaux, Y., Lepoivre, P., de Lapeyre de Bellaire, L., 2013b. The susceptibility of bananas to crown rot disease is influenced by geographical and seasonal effects. Can. J. Plant Pathol. 35, 27-36.

Finlay, A.R., Brown, A.E., 1993. The relative importance of Colletotrichum musae as a crownrot pathogen on Windward Island bananas. Plant Pathol. 42, 67-74.

Finlay, A.R., Lubin, C., Brown, A.E., 1992. The banana stalk as a source of inoculum of fungal pathogens which cause crown rot. Trop. Sci. 32, 343-352.

Forret, M., 2008. Etude de la variation de sensibilité des bananes d'exportation aux pourritures de couronne en fonction du stade de récolte. Travail de fin d'étude, Faculté des Sciences Agronomiques de Gembloux.

Frossard, P., Laville, E., Plaud, G., 1977. Etude des traitements fongicides appliqués aux bananes après récolte. III/.Action de l'imazalil. Fruits 32, 673-676.

Goos, R.D., Tschirsch, M., 1962. Effect of environmental factors on spore germination, spore survival, and growth of Gloeosporium musarum. Mycologia 54, 353-366.

Greene, G.L., Goos, R.D., 1963. Fungi associated with crown rot of boxed bananas. Phytopathology 53, 271-275.

Griffee, PJ., 1976. Pathogenicity of some fungi isolated from diseased crowns of banana hands. J. Phytopathol. 85, 206-216. 
Griffee, P.J., Burden, O.J., 1976. Fungi associated with crown rot of boxed bananas in the Windward Islands. J. Phytopathol. 85, 149-158.

Griffee, P.J., Pinegar, J.A., 1974. Fungicides for control of the crown rot complex: in vivo and in vitro studies. Trop. Sci. 16, 107-120.

Gunasinghe, R.N., Ikiriwatte, C.J., Karunaratne, A.M., 2004. The use of Pantoea agglomerans and Flavobacterium sp. to control banana pathogens. J. Horticultural Sci. Biotechnol. 79, 1002-1006.

Hostachy, B., Vegh, I., Leroux, P., Jacquemot, E., Foucher, S., Pigou, R., 1990. Bananes de la Martinique. Incidence des problèmes fongiques sur la qualité. Phytoma, 37-44.

Jeffries, P., Dodd, J.C., Jeger, M.J., Plumbey, R.A., 1990. The biology and control of Colletotrichum species on tropical fruit crops. Plant Pathol. 39, 343-366.

Jijakli, M., Lepoivre, P.C.G., 1999. Yeast species for biocontrol of apple postharvest diseases: an encouraging case of study for practical use. In: Upadhyay, R., Mukerij, K. (Eds.), Biotechnological approaches in biocontrol of plant pathogens. Kluwer Academic/Plenum publishers, New York, pp. 31-49.

Joas, J., 1997. Programme qualité de la banane d'exportation. Rapport d'essai sur l'emploi des UV en post récolte. Cirad-Flhor, Fort de France.

Joas, J., Malisart, S., 2001. Incidence des conditions d' application sur l' efficacite des fongicides utilises en post-recolte pour la banane [Effect of the application techniques on the effectiveness of the fungicides used in the banana postharvest]. Fruits 56, 383-394.

Johanson, A., Blasquez, B., 1992. Fungi associated with banana crown-rot on field-packed fruit from the Windward Islands and assessment of their sensitivity to the fungicides thiabendazole, prochloraz, and imazalil. Crop Prot. 11, 79-83.

Jones, D.R., 2000. Diseases of Banana. Abaca and Enset, Wallingford, UK.

Jones, D.R., Slabaugh, W.R., 1994. Banana diseases caused by fungi. Anthracnose. In: Ploetz, R., Zentmyer, G.A., Nishijima, W., Rohrbach, K.G., Ohr, H.D. (Eds.), Compendium of Tropical Fruit Diseases. APS Press, pp. 4-9.

Jullien, A., Chillet, M., Malezieux, E., 2008. Pre-harvest growth and development, measured as accumulated degree days, determine the post-harvest green life of banana fruit. J. Horticultural Sci. Biotechnol. 83, 506-512.

Jullien, A., Malezieux, E., Michaux-Ferriere, N., Chillet, M., Ney, B., 2001. Within-bunch variability in banana fruit weight: importance of developmental lag between fruits. Ann. Bot. 87, 101-108.

Kanapathipillai, V.S., Ahmad, R., Mahamad, M.I., 1987. The effect of sterile filtrates of Trichoderna spp and Penicillium spp and $4 \mathrm{kGy}$ irradiation on the spore germination of Colletotrichum musae. In: Singh, K.G., Manalo, P.L., Sastrontomo, S.S., et al. (Eds.), Movements of Pests and Control Strategies, pp. 283-292. Kuala Lumpur, Malaysia, ASEAN Plant Quarantine Centre and Training Institute, Selangor, Malaysia.

Khan, S.H., Aked, J., Magan, N., 2001. Control of the anthracnose pathogen of banana (Colletotrichum musae) using antioxidants alone and in combination with thiabendazole or imazalil. Plant Pathol. 50, 601-608.

Knight, C., 1982. Pathogenicity of some fungi associated with crown rot of bananas. Phytopathologische Zeitschrift 104, 13-18.

Krauss, U., 1996. Establishment of a bioassay for testing control measures against crown rot of banana. Crop Prot. 15, 269-274.

Krauss, U., Bidwell, R., Ince, J., 1998. Isolation and preliminary evaluation of mycoparasites as biocontrol agents of crown rot of banana. Biol. Control 13, 111-119.

Krauss, U., Johanson, A., 2000. Recent advances in the control of crown rot of banana in the Windward Islands. Crop Prot. 19, 151-160.

Lassois, L., Bastiaanse, H., Chillet, M., Jullien, A., Jijakli, M.H., De Lapeyre de Bellaire, L., 2010a. Hand position on the bunch and source-sink ratio influence the banana fruit susceptibility to crown rot disease. Ann. Appl. Biol. 156, 221-229. 
Lassois, L., Jijakli, H., Chillet, M., de Lapeyre de Bellaire, L., 2010b. Crown rot of bananas: Preharvest factors involved in postharvest disease development and integrated control methods. Plant Dis. 94, 648-658.

Lassois, L., Frettinger, P., de Lapeyre de Bellaire, L., Lepoivre, P., Jijakli, H., 2011a. Identification of genes involved in the response of banana to crown rot disease. Mol. Plant Microbe Interact. 24, 143-153.

Lassois, L., De Clerck, C., Frettinger, P., De Lapeyre De Bellaire, L., Lepoivre, P., Haissam Jijakli, M., 2011b. Catecholamine biosynthesis pathway potentially involved in banana defense mechanisms to crown rot disease. Commun. Agric. Appl. Biol. Sci. 76, 591-601.

Lassois, L., de Lapeyre de Bellaire, L., Jijakli, M.H., 2008. Biological control of crown rot of bananas with Pichia anomala strain K and Candida oleophila strain O. Biol. Control 45, 410-418.

Lim, J., Lim, T.H., Cha, B., 2002. Isolation and identification of colletotrichum musae from imported bananas. Plant Pathol. J. 18, 161-164.

Lukezic, FL., Kaiser, W.J., 1966. Aerobiology of Fusarium roseum 'Gibbosum' associated with crown rot of boxed bananas. Phytopathology 56, 545-548.

Lukezic, F.L., Kaiser, W.J., Martinez, M.M., 1967. The incidence of crown rot of boxed bananas in relation to microbial populations of the crown tissus. Can. J. Bot. 45, 413-421.

MacCracken, A.R., Swinburne, T.R., 1980. Effect of bacteria isolated from surface of banana fruits on germination of Colletotrichum musae conidia. Trans. Br. Mycol. Soc. 74,
212-214.

Marin, D.H., Sutton, T.B., Blankenship, S.M., Swallow, W.H., 1996. Pathogenicity of fungi associated with crown rot of bananas in Latin America on Grande Naine and diseaseresistant hybrid bananas. Plant Dis. 80, 525-528.

Marriott, J., Palmer, J.K., 1980. Bananas - Physiology and biochemistry of storage and ripening for optimum quality. CRC Crit. Rev. Food Sci. Nutr. 13, 41-88.

Meredith, D.S., 1962a. Some components of the air-spora in Jamaican banana plantations. Ann. Appl. Biol. 50, 577-594. Meredith, D.S., 1962b. Some fungi on decaying banana leaves in Jamaica. Trans. Br. Mycol.
Soc. 45, 335-347.

Meredith, D.S., 1971. Transport and storage diseases of bananas: biology and control. Trop.
Agric. 48, 35-50.

Mesturino, L., Ragazzi,A., 1988. Microorganismi fungini associati ai frutti di Musa, spp. presenti sul mercato italiano. Rivista di Agricoltura Subtropicale e Tropicale 82, 503-515.

Mondal, A.H., Parbery, D.G., 2005. The protective role of the spore matrix of Colletotrichum musae during rehydratation and exposure to extreme temperature and UV radiation. Aust. Plant Pathol. 34, 229-235.

Muirhead, I.F., Deverall, B.J., 1984. Evaluation of 3,4-dihydrobenzaldehyde, dopamine and its oxydation products as inhibitors of Colletotrichum musae (Berk. et Curt.) Arx in green
banana fruits. Aust. J. Bot. 32, 575-582.

Muirhead, I.F., Jones, D.R., 2000. Fungal diseases of banana fruit. Postharvest diseases. In: Jones, D.R. (Ed.), Diseases of Banana. Abaca and Enset, CABI, Wallingford, pp. 190-206.

Mulvena, D., Webb, E.C., Zerner, B., 1969.3,4-Dihydrobenzaldehyde, a fungistatic substance from green cavendish bananas. Phytochemistry 8, 393-395.

Nishijima, K.A., Miura, C.K., Armstrong, J.W., Brown, S.A., Hu, B.K.S., 1992. Effect of forced, hot-air treatment of papaya fruit on fruit quality and incidence of postharvest
diseases. Plant Dis. 76, 723-727.

Ogundero, V.W., 1987. Crown rot fungi of Nigerian bananas cv. Robusta and the effects of benomyl on their exo-enzymes. J. Basic Microbiol. 27, 43-47.

Peacock, B.C., 1973. Effect of Colletotrichum musae infections on the preclimacteric life of bananas. Queensland J.Agric. Animal Sci. 30, 239-246.

Peacock, B.C., Muirhead, I.F., 1974. Ethylene production by Colletotrichum musae. Queensland J.Agric. Animal Sci. 31, 249-252. 
PerezVicente, L., Hernandez,A., 2002. Reaction of Black Sigatoka resistant FHIA hybrids to Fusarium pallidoroseum and Colletotrichum musae causal agents of crown rot and anthracnose diseases of bananas. Phytopathology 92, S136.

Postmaster, A., Kuo, J., Sivasithamparam, K., Turner, D.W., 1997. Interaction between Colletotrichum musae and antagonistic microorganisms on the surface of banana leaf discs. Sci. Horticulturae 71, 113-125.

Ranasinghe, L., Jayawardena, B., Abeywickrama, K., 2002. Fungicidal activity of essential oils of Cinnamomum zeylanicum (L.) and Syzygium aromaticum (L.) Merr et L.M. Perry against crown rot and anthracnose pathogens isolated from banana. Lett. Appl. Microbiol. $35,208-211$.

Ranasinghe, L., Jayawardena, B., Abeywickrama, K., 2005. An intergrated strategy to control post-harvest decay of embul banana by combining essential oils with modified atmosphere packaging. Int. J. Food Sci. Technol. 40, 97-103.

Reyes, M.E.Q., Nishijima, W., Paull, R.E., 1998. Control of crown rot in 'Santa Catarina Prata' and 'Williams' banana with hot water treatments. Postharvest Biol. Technol. 14, 71-75.

Sangeetha, G., Thangavelu, R., Rani, S.U., Muthukumar,A., Udayakumar, R., 2010a. Induction of systemic resistance by mixtures of antagonist bacteria for the management of crown rot complex on banana. Acta Physiol. Plantarum 32,1177-1187.

Sangeetha, G., Thangavelu, R., Rani, S.U., 2010b. Evaluation of plant oils for suppression of crown rot disease and improvement of shelf life of banana (Musa spp. AAA subgroup, cv. Robusta). Int. J. Food Sci. Technol. 45, 1024-1032.

Sangeetha, G., Thangavelu, R., Usha Rani, S., Muthukumar, A., 2013. Antimicrobial activity of medicinal plants and induction of defense related compounds in banana fruits cv. Robusta against crown rot pathogens. Biological Control, 64, 16-25.

Shillingford, C.A., 1976. Occurence of banana fruit-rot fungi in Jamaican boxing plants. Plant Dis. Rep. 60, 788-793.

Shillingford, C.A., 1977. Control of banana fruit rots and of fungi that contaminate washing water. Trop. Sci. 19, 197-203.

Shillingford, C.A., 1978. Climatic factors affecting post-harvest decay of Jamaican bananas. J. Agric. Univ. Puerto Rico, 45-49.

Simmonds, J.H., 1941. Latent infection in tropical fruits discussed in relation to the part played by species of Gloeosporium and Colletotrichum. Proc. Royal Soc. Qld. 52, 92-120.

Simmonds, J.H., 1963. Studies in the latent phase of Colletotrichum species causing ripe rots of tropical fruits. Qld. J.Agric. Animal Sci. 20, 373-424.

Simmonds, J.H., Mitchell, R.S., 1940. Black end and anthracnose of the banana with special reference to Gloeosporium musarum Cke. and Mass. Bulletin of the. Council for Scientific and Industrial Research of Australia, Melbourne.

Slabaugh, W.R., Grove, M.D., 1982. Postharvest diseases of bananas and their control. Plant Dis. 66, 746-750.

Spalding, D.H., Reeder, W.F., 1978. Controlling market diseases of mangoes with heated benomyl. Proc. Florida State Horticultural Soc. 91, 186-187.

Stevens, C., Khan, V.A., Wilson, C.L., Lu, J.Y., Chalutz, E., Droby, S., 2005. The effect of fruit orientation of postharvest commodities following low dose ultraviolet light-C treatment on host induced resistance to decay. Crop Prot. 24, 756-759.

Stover, R.H., 1972. Banana, Plantain and Abaca Diseases. . Kew, Surrey, UK.

Su,Y.Y., Noireung, P., Liu, F, et al., 2011. Epitypification of Colletotrichum musae, the causative agent of 319 banana anthracnose. Mycoscience 52, 376-382.

Thompson,A.K., 1998. Controlled Atmosphere Storage of Fruits and Vegetables. Wallingford CABI.

Wallbridge, A., 1981. Fungi associated with crown-rot disease of boxed bananas from the Windward Islands during a two year survey. Trans. Br. Mycol. Soc. 77, 567-577.

Wallbridge, A., Pinegar, J.A., 1975. Fungi associated with crown-rot disease of bananas from St Lucia in the Windward Islands. Trans. Br. Mycol. Soc. 64, 247-254. 
Williamson, S.M., Guzmán, M., Marin, D.H., Anas, O., Jin, X., Sutton, T.B., 2008. Evaluation of Pseudomonas syringae strain ESC-11 for biocontrol of crown rot and anthracnose of banana. Biol. Control 46, 279-286.

Wills, R., McGlasson, W.B., Graham, D., Joyce, D.C., 1998. Postharvest. An Introduction to the Physiology and Handling of Fruit.Vegetables and Ornamentals, Wallingford.

Wilson, L.G., 1976. Handling of postharvest tropical fruit. Horticultural Sci. 11, 120-121.

Win, N.K.K., Jitareerat, P., Kanlayanarat, S., Sangchote, S., 2007. Effects of cinnamon extract, chitosan coating, hot water treatment and their combinations on crown rot disease and quality of banana fruit. Postharvest Biol. Technol. 45, 333-340. 